\title{
Microbial Endoxylanases: Effective Weapons to Breach the Plant Cell-Wall Barrier or, Rather, Triggers of Plant Defense Systems?
}

\author{
Tim Beliën, ${ }^{1}$ Steven Van Campenhout, ${ }^{1}$ Johan Robben, ${ }^{2}$ and Guido Volckaert ${ }^{1}$ \\ ${ }^{1}$ Katholieke Universiteit Leuven, Laboratory of Gene Technology, Kasteelpark Arenberg 21, B-3001 Leuven, Belgium; \\ ${ }^{2}$ Universiteit Hasselt en transnationale Universiteit Limburg, Biomedical Research Institute, Agoralaan, Gebouw A, B-3590 \\ Diepenbeek, Belgium
}

Submitted 12 May 2006. Accepted 12 June 2006.

\begin{abstract}
Endo- $\beta$-1,4-xylanases (EC 3.2.1.8) are key enzymes in the degradation of xylan, the predominant hemicellulose in the cell walls of plants and the second most abundant polysaccharide on earth. A number of endoxylanases are produced by microbial phytopathogens responsible for severe crop losses. These enzymes are considered to play an important role in phytopathogenesis, as they provide essential means to the attacking organism to break through the plant cell wall. Plants have evolved numerous defense mechanisms to protect themselves against invading pathogens, amongst which are proteinaceous inhibitors of cell wall-degrading enzymes. These defense mechanisms are triggered when a pathogen-derived elicitor is recognized by the plant. In this review, the diverse aspects of endoxylanases in promoting virulence and in eliciting plant defense systems are highlighted. Furthermore, the role of the relatively recently discovered cereal endoxylanase inhibitor families TAXI (Triticum aestivum xylanase inhibitor) and XIP (xylanase inhibitor protein) in plant defense is discussed.
\end{abstract}

Additional keywords: ethylene-inducing xylanase (EIX), glycoside hydrolase $(\mathrm{GH})$, hypersensitive response (HR), plant pathogens, signaling cascade.

Endo- $\beta$-1,4-xylanases (EC 3.2.1.8) (hereafter referred to as endoxylanases) are produced mainly by microorganisms but can also be found in plants, marine algae, protozoans, crustaceans, insects, and snails (Sunna and Antranikian 1997). Because of their ability to break down xylan, these enzymes are increasingly used in a number of biotechnological processes, including bread-making (Courtin et al. 1999), gluten-starch separation (Christophersen et al. 1997), improving nutritional properties of animal feed (Bedford and Schulze 1998), and the bleaching of cellulose pulp in paper manufacturing (Beg et al. 2001; Christov et al. 1999). However, not only have the various industrial applications of endoxylanases stimulated research on the biochemical and molecular aspects of this important enzyme of the family of glycosyl hydrolases. Being capable of degrading the plant cell wall, endoxylanases, especially from fungal origin, have also attracted attention because of their potential role in phytopathogenesis. Here, we outline the dual role of endoxylanases in promoting virulence of phytopatho-

Corresponding author: Tim Beliën; E-mail: tim.belien@biw.kuleuven.be genic microorganisms and in the induction of plant defense responses, with a focus on recent progress in these research topics.

Xylan, endoxylanases, and endoxylanase inhibitors.

The substrate of endoxylanases, xylan, is composed of $\beta-1,4-$ linked D-xylopyranosyl residues. This $\beta-(1,4) \mathrm{D}$-xylan main chain is commonly modified with various substituents, including $\alpha$-D-glucuronic or $\alpha$-4- $O$-methyl-D-glucuronic acid linked via $\alpha$-1,2-glycosidic bonds and $\alpha$-L-arabinofuranose linked via $\alpha$ 1,2 or $\alpha-1,3$ glycosidic bonds or both. The xylan can also be esterified with acetic acid at position 2 or 3 , or both, of xylopyranosyl units and with ferulic or $p$-coumaric acid at position 5 of arabinofuranosyl units (Kulkarni et al. 1999; Subramaniyan and Prema 2002). The degree of substitution and the nature of sidechains vary considerably between plant species and cell types (Ebringerová and Heinze 2000). Depending on the botanical origin, xylans are predominantly deposited in different parts of the plant, e.g., woody tissues, corn cobs, sunflower hulls, seeds, and cereal grains are very rich in xylan. It is typically located in the secondary cell wall, where it constitutes roughly $20 \%$ of the content, but in gramineous monocotyledonous plants, comparable relative amounts of xylan are also found in the primary cell wall. The abundant presence of xylan in the latter seems to interchange with pectin, and hence, both polysaccharides may perform similar roles in distinct plant cell-wall types (Carpita 1996). Endoxylanases catalyze the initial breakdown of xylan by hydrolyzing internal $\beta-1,4$ bonds in the polymer backbone and therefore play a key role in the degradation of this complex polysaccharide, although several other hydrolytic enzymes are needed for efficient and complete degradation (Shallom and Shoham 2003). The regions that accommodate xylose moieties are known as subsites, which are given a number prefixed with or + depending on whether they bind the glycone or aglycone region of the substrate, respectively, and by definition, the cleavage takes place between subsites -1 and +1 (Davies et al. 1997). Some endoxylanases are sterically hindered and require synergistic action of accessory enzymes like $\alpha$-arabinofuranosidases and $\alpha$-glucuronidases (Saha 2000). Endoxylanases belong mainly to glycoside hydrolase families 10 (GH10) and 11 (GH11), although some forms are also classified into families 5, 7, 8, and 43 (Collins et al. 2005).

GH10 endoxylanases typically have a high molecular weight $(\geq 30 \mathrm{kDa}$ ) and a low pI (Subramaniyan and Prema 2002). The overall structure of the catalytic domain of these 
enzymes is an eightfold $\beta / \alpha$ barrel resembling a 'salad bowl,' with the active site located in a cleft running across the barrel top. The functional domain may be accompanied by a carbohydrate-binding domain, which is in most cases, however, specific for cellulose (Kulkarni et al. 1999). Two glutamate moieties act as catalytic residues of the enzymatic reaction, which proceeds via a double displacement mechanism (Henrissat and Davies 1997; Rye and Withers 2000). GH10 endoxylanases are generally less selective than GH11 endoxylanases, and unlike the latter, they are able to attack decorated forms of the polysaccharide (Biely et al. 1997). Furthermore, GH10 endoxylanases tend to release shorter oligosaccharides.

GH11 endoxylanases are generally characterized by a low molecular mass (typically around $22 \mathrm{kDa}$ ) and a high $\mathrm{pI}$, although endoxylanases exhibiting acidic pI values also are naturally occurring in this family (Törrönen and Rouvinen 1997). Their structure adopts a $\beta$-jelly roll fold, which has been likened to a right hand with a two- $\beta$ strand 'thumb' forming a lid over the active site located in the 'palm' (Törrönen et al. 1994). In consonance with GH10 endoxylanases, two glutamates are implicated in the enzymatic hydrolysis, with retention of anomeric configuration via a double-displacement mechanism. However, GH11 endoxylanases are usually more selective and release larger oligosaccharides, since substituents represent a more serious hindrance to their activity (Biely et al. 1997). Only a few members of GH11 are reported to be modular proteins (Törrönen and Rouvinen 1997).

Like many other carbohydrate-active enzymes, proteinaceous inhibitors of endoxylanases were found to be present in plants. In the late 1990s, their existence was demonstrated for the first time by Debyser and associates (1997), after observing inhibition of endoxylanase activities by wheat-flour protein extracts. Subsequently, proteins representing a first type of endoxylanase inhibitors were purified from wheat flour and were named TAXI (Triticum aestivum xylanase inhibitor) (Gebruers et al. 2004). Apart from this work, McLauchlan and associates (1999) discovered a second type of proteinaceous endoxylanase inhibitor in wheat, further referred to as XIP (xylanase inhibitor protein), with inhibition specificities and structural properties different from those of TAXI-type proteins (Juge et al. 2004). TAXI and XIP-type inhibitors have been widely found in cereals (rye, barley, maize, oats, rice, durum, and bread wheat) (Beaugrand et al. 2006; Durand et al. 2005; Goesaert et al. 2004, 2005), and based on sequence data, it can be assumed that they are widespread within the plant kingdom (Durand et al. 2005; Raedschelders et al. 2004). Only recently, a third type of endoxylanase inhibitor belonging to the thaumatin protein family could be identified, which was termed thaumatinlike xylanase inhibitor (Beaugrand et al. 2006). In addition to these endoxylanase inhibitors of plant origin, the existence of a powerful bifunctional alkalo-thermophilic Bacillus sp. inhibitor of fungal endoxylanases and aspartic proteinases has been reported (Dash et al. 2001). The potential of endoxylanase inhibitors to affect the functionality of endoxylanases in cerealbased biotechnological processes was recently demonstrated (Frederix et al. 2004; Trogh et al. 2004).

TAXI-type endoxylanase inhibitors are approximately 40$\mathrm{kDa}$ proteins with high $\mathrm{pI}$ values $(\geq 8.0)$ (Gebruers et al. 2004) that occur in two molecular forms, $\mathrm{A}$ and $\mathrm{B}$. Form $\mathrm{A}$ is the fulllength protein, while form B is its proteolytically processed counterpart, which consists of two polypeptide chains of approximately 28 to 30 and 10 to $12 \mathrm{kDa}$ that are connected by disulfide bonds. In contrast to XIP, TAXI inhibitors appear to be specific for GH11 endoxylanases from both bacterial and fungal origin but do not affect GH10 endoxylanases (Gebruers et al. 2004). The originally identified TAXI protein was further found to be a mixture of TAXI-I and TAXI-II, which can be differentiated by their different inhibition activity towards GH11 endoxylanase ExlA from Aspergillus niger and their different pI values (Gebruers et al. 2001). Recently, the existence of TAXI-III and TAXI-IV has been reported (Igawa et al. 2005). However, the inhibition specificity of TAXI-III, as determined by these authors, corresponds to that of TAXI-I, while the specificity of TAXI-IV has not yet been reported. Site-directed mutations of Asp37 of ExlA (Tahir et al. 2004) and Asp11 of XynA (Sørensen and Sibbesen 2006) completely abolish TAXI-I-mediated inhibition of these GH11 endoxylanases from Aspergillus niger and Bacillus subtilis, respectively. Furthermore, the reported crystal structure of TAXI-I in complex with ExlA indicates the importance of the C-terminus for the differences in endoxylanase specificity among different TAXI-type inhibitors (Sansen et al. 2004). This was further explored using site-directed mutagenesis, demonstrating that His374 of TAXI-I stabilizes complex formation (Fierens et al. 2005) and that TAXI-II inhibition specificity bears on the identity of two key residues at positions 294 and 376, which are involved in the interaction at the -2 glycone subsite and the active site of GH11 endoxylanases, respectively (Raedschelders et al. 2005).

XIP-type endoxylanase inhibitors are glycosylated monomeric proteins of approximately $30 \mathrm{kDa}$ with pI values of 8.0 to 9.0 (Durand et al. 2005; Goesaert et al. 2005; Juge et al. 2004). The amino-acid sequence of XIP-I shows overall homology with chitinases belonging to glycosyl hydrolase family 18 . However, although XIP-I possesses a triosephosphate isomerase-barrel $(\beta / \alpha)_{8}$-fold and displays structural features typical of this family (Payan et al. 2003), it does not hydrolyze chitin (Elliott et al. 2002; McLauchlan et al. 1999) and, thus, represents a novel class of 'chitinase-like' inhibitors. Out of a range of fungal and bacterial endoxylanases from both GH10 and GH11 families tested for XIP-sensitivity, only those of fungal origin were inhibited by XIP, with the exception of the fungal GH10 Aspergillus aculeatus endoxylanase (Flatman et al. 2002; Juge et al. 2004). This apparent specific inhibition of fungal endoxylanases is not due to the binding of XIP-I to glycosylation sites on the fungal enzymes, since both the native and Escherichia coli-expressed recombinant forms of Penicillium funiculosum endoxylanase are inhibited to the same extent (Brutus et al. 2004). However, on the basis of the crystal structures of XIP-I in complex with Aspergillus nidulans (GH10) and Penicillium funiculosum (GH11) endoxylanases and the structural determinants of XIP-I specificity derived thereof, Payan and associates (2004) postulated that the inhibitor is able to interact with GH10 and GH11 endoxylanases of both fungal and bacterial origin. Furthermore, these authors showed that XIP-I possesses two independent enzyme-binding sites for GH10 and GH11 endoxylanases and that XIP-mediated inhibition involves substrate-mimetic contacts and interactions occluding the active site. This is in agreement with site-directed mutagenesis studies and the observed competitive mode of inhibition (Tahir et al. 2002, 2004).

\section{Endoxylanases as components}

\section{of the offensive arsenal of plant pathogens.}

It is now well established that phytopathogenic microorganisms secrete a number of hydrolytic enzymes capable of degrading cell-wall polymers to invade the plant tissue and feed on the released nutrients (Walton 1994). Nevertheless, so far only few cell wall-degrading enzymes have been reported to be important pathogenicity factors by demonstrating that their loss had significant impact on the pathogenicity of the microorganism. The majority of these reports refer to pectin-degrading enzymes such as polygalacturonases, pectin methylesterases, and pectate lyases (D'Ovidio et al. 2004). In fact, this is not 
too surprising, considering that, for many years, research on cell wall-degrading enzymes has focused on pectic enzymes from phytopathogens of dicotyledonous plants. However, unlike in dicotyledonous plants, pectin is only a minor constituent of graminaceous cell walls, which consist mainly of hemicellulose (Carpita 1996). Since xylans represent a large proportion of the hemicellulosic fraction of cereal cell-wall matrices, xylan-degrading enzymes are expected to be important components of the offensive arsenal of cereal pathogens (Cooper et al. 1988; Wanjiru et al. 2002) and may have a role similar to that of pectic enzymes in infection of dicotyledons. Indeed, during the past 20 years, several indications suggesting that endoxylanases might be pathogenicity factors for phytopathogenic microorganisms have been reported. Traditionally, this indirect evidence has been obtained by analyzing the production of cell wall-degrading enzymes upon infection or by examining the effect of (partially) purified endoxylanase on plant cells and infected tissues. For instance, bacterial strains of $\mathrm{Er}$ winia chrysanthemi that infect maize were found to secrete more endoxylanase activity than strains that infect only dicotyledonous plants (Braun and Rodrigues 1993), and fungal pathogens, such as Septoria nodorum, that infect graminaceous monocotyledons are reported to secrete more xylan-degrading enzymes than pectinases (Cooper et al. 1988; Lehtinen 1993). Fusarium-infected barley was also found to contain considerable amounts of exogenous endoxylanase (Schwarz et al. 2002). A high pI endoxylanase is one of the most abundant enzymes produced by Stagonospora nodorum when grown on wheat cell walls, and moreover, in its pure form, it is able to degrade the wheat cell wall (Carlile et al. 2000). Furthermore an endoxylanase from fungal origin was shown to be capable of killing rice cells (Ishii 1988). Additional evidence supporting a role for microbial endoxylanases in pathogenicity has been achieved by cytological and molecular techniques. For example, using tissue-printing and immunostaining analyses, Giesbert and associates (1998) demonstrated that endoxylanases were exclusively present in rye ovaries infected with Claviceps purpurea, strongly suggesting that Claviceps purpurea secretes endoxylanase while colonizing its host. During the last decade, the identification and cloning of endoxylanase coding genes (Table 1) has opened perspectives for even more stringent approaches to determine the role of endoxylanases in plant pathogenesis, e.g., by the application of gene-disruption techniques or mRNA expression analyses. Furthermore, the use of molecular genetic techniques has allowed the detailed investigation of individual, recombinant endoxylanases. For instance, heterologous expression and subsequent purification of XynA from a corn strain of Erwinia chrysanthemi enabled Hurlbert and Preston (2001) to perform an extensive functional characterization of the enzymatic properties of this endoxylanase. Based on the size of the resulting oligoxyloside products, it was suggested that XynA has a role in loosening the cell-wall structure of the host, thereby allowing other enzymes secreted by the pathogen to gain better access to the host tissue, rather than to participate in a pathway for the catabolism of the hemicellulose (Hurlbert and Preston 2001).

The expression pattern of several endoxylanases from at least seven phytopathogenic microorganisms has been determined. The genes encoding Xyn22, Xyn33, and Xyl-6 of Magnaporthe grisea were found to be expressed when the fungus was grown on rice cell walls but not when grown on sucrose (Wu et al. 1995). Subsequent detailed analysis using reverse transcriptase-polymerase chain reaction (RT-PCR) revealed that xyn 22 and xyn33 transcripts are barely present in infected rice seedlings at $46 \mathrm{~h}$, accumulated to maximum at $84 \mathrm{~h}$, and declined in amount by $96 \mathrm{~h}$ postinoculation (Wu et al. 2006). On the other hand, transcripts of $x y l-6$ were detectable as early as $24 \mathrm{~h}$ postinoculation and accumulated to a PCR-saturated level $68 \mathrm{~h}$ postinoculation. In addition, $x y l-6$ is expressed more strongly than xyn22 and xyn33, both in culture with rice cell wall as a carbon source and in infected rice leaves ( $\mathrm{Wu}$ et al. 2006). Thus, although expression of endoxylanases from this phytopathogenic fungus is under control of general regulatory mechanisms (e.g., catabolite repression; Kulkarni et al. 1999)

Table 1. Overview of endoxylanase genes cloned from phytopathogenic microorganisms

\begin{tabular}{|c|c|c|c|c|}
\hline Gene & Glycosyl hydrolase family & Phytopathogenic microorganism $^{a}$ & GenBank accession no. & Reference \\
\hline xyll & 11 & Ascochyta pisi & Z68891 & Lübeck et al. 1997 \\
\hline$x y n B c 1$ & 11 & Botrytis cinerea & $\ldots^{\mathrm{b}}$ & Brutus et al. 2005 \\
\hline xyn11A & 11 & & DQ057980 & Brito et al. 2006 \\
\hline xyll & 11 & Cochliobolus carbonum & L13596 & Apel et al. 1993 \\
\hline$x y l 2$ & 11 & & U58915 & Apel-Birkhold and Walton 1996 \\
\hline xyl3 & 11 & & U58916 & \\
\hline xyl4 & 10 & & AY622513 & Tonukari et al. 2002 \\
\hline$x y l 2$ & 11 & Cochliobolus sativus & AJ004802 & Emami and Hack 2001 \\
\hline xyll & 11 & Claviceps purpurea & Y16969 & Giesbert et al. 1998 \\
\hline$x y l 2$ & 10 & & Y16970 & \\
\hline xynA & 5 & Erwinia chrysanthemi & U41750 & Keen et al. 1996 \\
\hline xylA & 11 & Fusarium graminearum & AY289919 & Beliën et al. 2005 \\
\hline$x y l B$ & 11 & & AJ863566 & \\
\hline$x y l 2$ & 10 & Fusarium oxysporum f. sp. lycopersici & AF052583 & Ruiz-Roldan et al. 1999 \\
\hline xyl3 & 10 & & AF052582 & \\
\hline xyl4 & 11 & & AF246831 & Gómez-Gómez et al. 2002 \\
\hline xyl5 & 11 & & AF246830 & Gómez-Gómez et al. 2001 \\
\hline htxyl1 & 11 & Helminthosporium turcicum & AJ238895 & Degefu et al. 2001 \\
\hline htxyl2 & 11 & & AJ548879 & Degefu et al. 2004 \\
\hline xyn 22 & 11 & Magnaporthe grisea & L37529 & Wu et al. 1995 \\
\hline xyn33 & 10 & & L37530 & \\
\hline$x y l-3$ & 11 & & AY144350 & Wu et al. 2006 \\
\hline$x y l-4$ & 11 & & AY144349 & \\
\hline$x y l-5$ & 10 & & AY144348 & \\
\hline xyl-6 & 10 & & AY124591 & \\
\hline xynA & 10 & Xanthomonas oryzae pv. oryzae & AF331922 & Rajeshwari et al. 2005 \\
\hline$x y n B$ & 10 & & AF331922 & \\
\hline
\end{tabular}

a Names of species are copied as mentioned in the referred work, and hence, the mixing of anamorph and teleomorph names.

${ }^{\mathrm{b}}$ No GenBank accession number is available. 
as reported for many endoxylanases from nonpathogenic microorganisms, each endoxylanase gene exhibits a unique expression pattern influenced by specific conditions, including the stage of infection. This was also observed for other endoxylanases of phytopathogenic origin. For instance, RT-PCR analysis revealed that $x y l 5$ and $x y l 2$ from Fusarium oxysporum f. sp. $l y-$ copersici are expressed exclusively during the initial and final stages of disease, respectively, whereas $x y l 3$ and $x y l 4$ are expressed throughout the entire cycle of infection on tomato plants (Gómez-Gómez et al. 2001, 2002; Ruiz-Roldan et al. 1999). Also the endoxylanases of the maize pathogens Cochliobolus carbonum and Helminthosporium turcicum were found to display a differential expression pattern. ApelBirkhold and Walton (1996) reported that $x y l 1$ as well as $x y l 3$ but not $x y l 2$ mRNAs from Cochliobolus carbonum are present in infected plants. Abundant htxyl2 transcript was detected at early and late stages of infection by Helminthosporium turcicum, whereas no detectable htxyll transcript was found by Northern blot analysis (Degefu et al. 2004). In addition, it could be shown that two endoxylanase genes from Claviceps purpurea were expressed during all infection stages in rye, although Giesbert and associates (1998) suggested that detailed analyses such as quantitative PCR might show phase-specific variation in their expression. Western blot analysis revealed that XynB from the rice pathogen Xanthomonas oryzae pv. oryzae is released into the xylem sap during in planta growth of the bacterium (Rajeshwari et al. 2005). Using semiquantitative RT-PCR, Brutus and associates (2005) demonstrated that $x y n B c 1$ mRNAs of Botrytis cinerea accumulate during early stages of infection on tobacco leaf tissue. However, no endoxylanase activity could be detected at the early stages of infection. Also, during infection of bean leaves, significant activity of Botrytis cinerea endoxylanase could only be observed from 36 $\mathrm{h}$ after inoculation, while aggressive infection had already started by 24 h (von Tiedemann 1997). Recently, quantitative PCR was used to reveal the presence of transcripts of another Botrytis cinerea GH11 endoxylanase gene, xyn11A, during infection of tomato leaves. Expression of xyn $11 A$ was detected from the beginning of the infection in the fresh-inoculated leaves, but in contrast to the constitutive expression of $x y \mathrm{BCCl}$ during infection of tobacco (Brutus et al. 2005), the level of xyn11A transcripts significantly increased between 24 and $48 \mathrm{~h}$ postinoculation (Brito et al. 2006). This expression pattern during the first two days of infection was identical to the one observed by Schulze Gronover and associates (2004) with the same endoxylanase gene in the Botrytis cinerea-bean interaction. The latter study additionally demonstrated that the levels of xyn11A transcript remained stable between 44 and $68 \mathrm{~h}$ postinoculation. It is noteworthy that a close inspection of the amino-acid sequences of XynBc1 and Xyn11A reveals that both endoxylanases are nearly identical proteins differing only at residues 48 (Asp/Ala), 99 (Phe/Ser), 145 (Ile/Val), and 188 (Asp/Asn). Probably, $x y n B c 1$ and $x y n 11 A$ represent the same endoxylanase gene and these substitutions are due to sequence polymorphisms between the Botrytis cinerea strains used in the cited studies (B05-10 vs. SAS56).

The differential expression patterns of the endoxylanase genes during pathogenesis suggest their involvement in infection and establishment of disease. However, so far targeted disruption of none of the individual endoxylanase genes from Cochliobolus carbonum (Apel et al. 1993; Apel-Birkhold and Walton 1996), Fusarium oxysporum (Gómez-Gómez et al. 2001, 2002), Erwinia chrysanthemi (Keen et al. 1996), and Magnaporthe grisea (Wu et al. 1995) has been reported to dramatically affect pathogenicity. Genetic redundancy or the occurrence of multiple endoxylanases in microorganisms has been put forward as one of the main reasons why the gene dis- ruption mutants of endoxylanases remain pathogenic (ApelBirkhold and Walton 1996; Gómez-Gómez et al. 2002). To date, there are no mutants of the above-mentioned phytopathogenic microorganisms in which all of the endoxylanase genes have been disrupted, and therefore, the definitive role of endoxylanases in phytopathogenesis of many of these microorganisms still remains an open question. However, an alternative approach to evaluate the role of multiple endoxylanases in pathogenesis is the disruption of transcriptional regulators or conserved signal transduction components, as these proteins normally affect whole sets of endoxylanase genes. In this context, a Cochliobolus carbonum mutant disrupted in $S N F 1$, a gene encoding a protein kinase required for expression of catabolite-repressed genes, showed reduced virulence and strongly reduced expression of cell wall-degrading enzymes, including endoxylanases (Tonukari et al. 2000). In screening for genes under control of the Botrytis cinerea $\mathrm{G} \alpha$ subunit of a heterotrimeric $\mathrm{G}$ protein, $\mathrm{Bcg} 1$, a protein required for virulence, two endoxylanase genes were identified (Schulze Gronover et al. 2004). Both genes are expressed in planta in the wild type but not in the bcgl mutant or in a mutant for the adenylate cyclase gene bac. Furthermore, Ray and associates (2000) demonstrated that mutations in the structural genes of the terminal branch of the type II secretion system (T2S), xpsD and xpsF (Xanthomonas protein secretion genes $\mathrm{D}$ and $\mathrm{F}$ ), reduced virulence of $X$. oryzae pv. oryzae and resulted in endoxylanase accumulation in the periplasmic space. In addition, the T2S pathway structural gene $x p s E$ was reported to be required for endoxylanase and cellulase secretion and full virulence in Xanthomonas oryzae pv. oryzae (Sun et al. 2005). Further research revealed that mutation of $x y n B$, an endoxylanase gene identified subsequently, partially affects virulence of the pathogen (Rajeshwari et al. 2005). However, severe virulence deficiency required the simultaneous inactivation of another T2S secreted protein, the lipase/esterase LipA, illustrating the functional redundancy among the T2S secreted proteins of Xanthomonas oryzae pv. oryzae in promoting virulence on rice. It was only recently that experimental evidence demonstrating the requirement of a single endoxylanase for virulence could be obtained. Brito and associates (2006) showed that deletion of xyn 11A from Botrytis cinerea strongly affected its ability to infect tomato leaves and grape berries. The appearance of secondary lesions on tomato leaves was delayed, and the average size for those infections that were actually spreading was reduced by more than $70 \%$. Strikingly, the mutant strain had only a moderate decrease, about $30 \%$, in the level of extracellular endoxylanase activity.

Endoxylanases as elicitors of defense responses in plants.

The interaction between plants and pathogens induces a diverse battery of defense mechanisms, including cell wall strengthening, de novo production of antimicrobial compounds, ethylene biosynthesis, and rapid localized cell death (Atkinson 1993; Greenberg 1997; Morel and Dangl 1997). These defense responses are triggered by pathogen-derived molecules that have been termed elicitors. Proteins exhibiting hydrolytic activity, as well as different cell-wall constituents, originating either from the invading pathogen or host plant have been identified as elicitors (Bucheli et al. 1990; Esquerré-Tugayé et al. 2000). In this context certain endoxylanases are known to be active elicitors (Dean et al. 1989). An endoxylanase from Trichoderma viride, referred to as the ethylene-inducing xylanase (EIX), has been used most extensively to study elicitor activity of endoxylanases. When applied to tobacco (Bailey et al. 1990, 1992), pepper, and tomato plants (Avni et al. 1994a), this 22-kDa GH11 endoxylanase induces ethylene production and rapid cell death, symptoms associated with the hypersensitive response (HR). Of major interest in this respect is the fact 
that, although HR might provide an effective defense against biotrophic pathogens, it is known to facilitate infection by necrotrophic pathogens (Glazebrook 2005). Regarding this, the relevance of endoxylanases in pathogenesis would particularly hold true for necrotrophic pathogens, and differential expression of endoxylanase genes in hemibiotrophic pathogens may be associated with switching from the biotrophic relationship to the necrotrophic phase.

The tomato cultivar M82 responds to EIX treatment, while a near-isogenic line, cultivar IL75, does not (Avni et al. 1994a). In line with this, also the response of tobacco to EIX was found to be cultivar specific (Bailey et al. 1993). Ron and associates (2000) mapped the EIX-responding locus in tomato by high-resolution linkage analysis. Earlier, Hanania and Avni (1997) had reported the existence of a high affinity-binding site for the EIX elicitor only in membranes of tobacco and tomato that are genetically capable of responding to the elicitor. This, together with the observation that EIX is able to elicit ethylene biosynthesis in protoplasts (lacking most of the cell wall), strongly suggested that the elicitor activity of the endoxylanase is solely based on its specific recognition by a plant protein (Sharon et al. 1993). However, it could not be excluded that the release of cell-wall fragments by the enzymatic xylandegrading activity takes part in the elicitation process. Two independent studies addressed this question by creating enzymatically inactive forms of XynII from Trichoderma reesei (Enkerli et al. 1999) and EIX (Furman-Matarasso et al. 1999) through site-directed mutagenesis of residues in the catalytically active sites. In both studies, enzymatically inactive mutants were obtained that retain elicitor activity, proving that endoxylanase activity is not necessary for elicitor activity. Furthermore, the elicitation epitope on EIX responsible for inducing the hypersensitive-like response has been recently elucidated (Rotblat et al. 2002). Through the generation of EIX-specific polyclonal antibodies and screening of phage-displayed combinatorial peptide libraries an essential sequence of the EIX elicitation activity has been identified. This sequence consists of the pentapeptide TKLGE mapped to an exposed $\beta$-strand of EIX. Replacing the pentapeptide TKLGE by VKGT inhibited the elicitation activity but not the enzymatic activity of the EIX protein, further demonstrating that endoxylanase activity is unrelated to the elicitation process (Rotblat et al. 2002). By checking the Pfam database entry of GH11 endoxylanases (accession number PF00457), we only found the TKLGE motif in endoxylanases originating from Trichoderma spp. and not from any other saprophytic or pathogenic microbes. In line with this is the intriguing fact that a hypersensitive-like response of plants to endoxylanases from microbes other than Trichoderma has so far not been reported.

Recently, two genes, LeEixl and LeEix2, the products of which act as receptors for EIX, were identified at the EIXresponding locus of tomato (Ron and Avni 2004). Both genes showed homology to the $V e$ and $C f$ resistance genes in tomato, and the encoded proteins contain a Leu zipper, an extracellular Leu-rich repeat domain with glycosylation signals, a transmembrane domain, and a C-terminal domain with a mammalian endocytosis signal. Although both gene products were able to bind the EIX elicitor independently, only LeEix 2 was found to be capable of transmitting the hypersensitive-like response induction signal (Ron and Avni, 2004). Furthermore, diverse signaling cascades have been implicated in response to pathogenic elicitation in plants treated with endoxylanase. Phospholipase C and D, two plant signaling enzymes active in distinctive enzymatic routes for the generation of the lipid second-messenger phosphatidic acid, are activated in response to elicitation of suspension-cultured tomato cells with EIX (van der Luit et al. 2000). Laxalt and associates (2001) demonstrated that expression of one phospholipase $\mathrm{D}$ gene, $L e P L D \beta 1$, is specifically upregulated after endoxylanase treatment. $L e P L D \beta 1$-silenced cell-suspension cultures exhibit a strong decrease in endoxylanaseinduced phopholipase D activity and respond to endoxylanase treatment with a disproportionate oxidative burst (Bargmann et al. 2006). In addition, $L e P L D \beta 1$-silenced cells had higher polyphenol oxidase activity, secreted less of the endogenous $\beta$-D-xylosidase LeXYL2, and expressed and secreted more xyloglucanspecific endoglucanase inhibitor protein XEGIP. Interestingly, the latter displays sequence similarity with TAXI-type endoxylanase-inhibiting proteins (Raedschelders et al. 2004). Furthermore, a phospholipase D-mediated accumulation of extracellular $N$-acylethanolamines (NAE) was detected in tobacco cell suspensions (Chapman et al. 1998) and leaves (Tripathy et al. 1999) treated with endoxylanase. One of these NAE, $N$-myristoylethanolamine (NAE 14:0), activates expression of Phe ammonia lyase-encoding plant defense genes in a manner similar to endoxylanase treatment (Tripathy et al. 1999). Additionally, Tripathy and associates (2003) observed high-affinity specific binding activity for NAE 14:0 in tobacco, supporting the existence of an NAE-signaling pathway that participates in endoxylanase elicitor perception. Another defense signaling pathway that plays a role in the response to elicitation with endoxylanase is the mitogen-activated protein (MAP) kinase cascade. Indeed, the tomato MAP kinase LeMPK3 is induced at the mRNA level upon treatment with EIX (Mayrose et al. 2004). Further detailed characterization of LeMPK3 revealed that it exhibits a dual phosphorylation specificity, which prompted Mayrose and associates (2004) to propose that it represents a convergence point for different signaling pathways leading to the activation of tomato defense responses. Apart from this work, the induction of MAP kinase-like activities has been observed in the hypersensitive-like cell death of tobacco cells treated with EIX (Suzuki et al. 1999) and in HR-associated disease resistance (Yang et al. 2001; Yap et al. 2005; Zhang and Liu, 2001). However, despite the involvement of their enzymatic activity in elicitor-signaling, Suzuki and associates (2006) noticed that the expression of MAP kinases, as well as other cell cycle-related genes, in this instance cyclin genes, is reduced upon endoxylanase treatment of tobacco cells. Protein phosphorylation was further shown to be involved in the regulation of endoxylanase-activated GCC box- and $\mathrm{W}$ box-mediated transcription of a tobacco class I basic chitinase gene (Yamamoto et al. 1999, 2004). The latter studies additionally provided clear indications for the involvement of various GCC and W box-binding ethylene-responding transcription factors in the endoxylanase-induced transcription of defense genes. In addition to the activation of defense genes, protein kinase activity is required for the repression of cyclin genes in tobacco (Suzuki et al. 2006). The increase in ethylene biosynthesis in planta upon treatment with EIX is also accompanied by the accumulation of 1-aminocyclopropane-1-carboxylic acid (ACC), an increase in extractable ACC synthase (Acs) activity, and increases in Acs and ACC oxidase transcripts (Avni et al. 1994b). Recently, a cis element in the promoter of an ACC synthase gene, LeAcs2, from tomato was found to be essential for induction by EIX (Matarasso et al. 2005). Subsequently, a cysteine protease from tomato, $\mathrm{LeCp}$, that binds to the cis element and activates LeAcs 2 gene expression, was isolated. In tobacco, another class of proteases, namely serine proteases, is involved in the hypersensitive-like response upon EIX-mediated elicitation, but in this case, proteolytic activity was suggested to be responsible for signal transduction (Yano et al. 1999).

\section{Role of endoxylanase inhibitors in plant defense.}

To defend themselves against cell wall-degrading enzymes secreted by phytopathogenic microorganisms, plants appear to have evolved proteinaceous inhibitors of these enzymes. Such 
inhibitors may limit pathogen invasion either by just reducing the hydrolytic activity of the cell wall-degrading enzymes or by ensuring the generation of elicitor-active polysaccharide fragments that might have been extensively degraded in the absence of the inhibitors (Esquerré-Tugayé et al. 2000). The inhibitors that are studied in most detail in this context are the polygalacturonase-inhibiting proteins, which are found in a variety of dicotyledonous plants and pectin-rich monocotyledonous plants (De Lorenzo et al. 2001). Recently, direct evidence of the involvement of this type of inhibitor in plant defense has been reported (De Lorenzo and Ferrari, 2002; D'Ovidio et al. 2004).

Also, the relatively large amounts of endoxylanase inhibitors in grains (typically 50 to 100 and 200 to $300 \mathrm{ppm}$ for TAXI and XIP-type proteins, respectively) suggests they have a role in plant resistance to pathogen infection. Indeed, several lines of indirect evidence suggest their involvement in plant defense through counteracting endoxylanases secreted by phytopathogenic microorganisms. Firstly, TAXI as well as XIPtype inhibitors are specific for exogenous endoxylanases and exhibit no inhibition activity towards known endogenous cereal endoxylanases (Gebruers et al. 2004; Juge et al. 2004). Therefore, it is unlikely that both types of inhibitors act as regulators of physiological processes such as mobilization of endosperm reserves and remodeling of plant cell walls during growth and development. The intricate recognition specificities of both inhibitors towards diverse endoxylanases from specifically microbial origin might be the result of plant evolution to counteract the many endoxylanases secreted by bacteria and fungi, analogous to polygalacturonase-inhibiting proteins (Payan et al. 2004; Sansen et al. 2004, D'Ovidio et al. 2004). Noteworthy, however, is the fact that XIP-I has the capacity to inhibit plant enzymes (two $\alpha$-amylase isozymes of barley) in addition to inhibition of exogenous endoxylanases (Sancho et al. 2003). So far, endoxylanases from two phytopathogenic microorganisms have been tested for inhibition by TAXI and XIP. Two GH11 endoxylanases from Fusarium graminearum are inhibited by TAXI-I but not by XIP-I (Beliën et al. 2005). The latter was an unexpected result, as XIP had previously been postulated to be typically active against endoxylanases produced by fungi (Juge et al. 2004). In line with the previously reported inhibition specificities of both inhibitors, TAXI-I as well as XIP-I are able to inhibit the GH11 endoxylanase, XynBc1, from Botrytis cinerea (Brutus et al. 2005). Strikingly, from the four amino-acid differences that distinguish XynBc1 from Xyn11A, the only endoxylanase to date of which the individual activity has unambiguously been demonstrated to be required for pathogenesis (Brito et al. 2006), two residues are located at XIP-I interaction positions $\left(\mathrm{Ala}^{48}\right.$ and Val ${ }^{145}$ ). Furthermore, no inhibition of XynBc1 by TAXI-II was observed (Brutus et al. 2005). Taken together, these findings suggest a coevolutionary arms race, i.e., a dance of adaptation and counter-adaptation, in which plants evolved different classes of inhibitors to counteract the many endoxylanases secreted by phytopathogens while the latter evolved to produce multiple endoxylanases with distinct sensitivities towards endoxylanase inhibitors.

Secondly, both types of inhibitors show sequence homology with proteins that are known to counteract invading pathogens or, at least, are thought to be involved in plant defense. As stated above, XIP shows high sequence and structural homology with Class III chitinases. These enzymes have been classified as pathogenesis-related proteins because of their inducible expression upon infection by pathogens (Yu and Guo 2000). Chitinolytic activities are found to counteract invading pathogens by degrading polysaccharides of their cell wall (Punja and Zhang 1993). This direct antifungal activity is accompa- nied by an indirect defense action through releasing oligosaccharide elicitors from fungal chitin (Sahai and Manocha 1993). Plant chitinases evolve rapidly, suggesting that they are critical in the coevolution of plants and pathogens (Bishop et al. 2000). It is thus likely that XIP proteins have evolved from chitinases whose synthesis was already triggered by fungal attack, but instead of interacting with chitin, this new class of proteins developed endoxylanase inhibitory activity (Durand et al. 2005). In this way, evolution might have retained the existing signal recognition and expression-regulation pathways.

TAXI shows high protein sequence similarity with extracellular dermal glycoproteins (Fierens et al. 2003). The latter have been considered to play a role in plant defense due to their rapid increase of expression in response to wounding and their localization in epidermis and dermal tissues (Satoh et al. 1992). Noticeably, TAXI proteins were also found to be more abundant in the wheat kernel outer tissues (Gebruers et al. 2002). Furthermore, as mentioned above, TAXI displays sequence similarity with xyloglucan-specific endoglucanase inhibitor protein XEGIP (Raedschelders et al. 2004), which has been ascribed a role in plant defense by inhibiting microbial glucanases of glycosyl hydrolase family 12 (Qin et al. 2003). This is particularly interesting, since GH12 glucanases share a common $\beta$-sandwich fold with GH11 endoxylanases. Noteworthy in this context is the recent identification of a TAXIresembling protein that belongs to the nectar proteins from tobacco and which has been proposed to protect the gynoecium from microbial invasion, as a potent inhibitor of fungal endoglucanases (Naqvi et al. 2005). Analysis of the TAXI-I structure further indicated that TAXI-type endoxylanase inhibitors have divergently evolved from an aspartic proteinase ancestor (Sansen et al. 2004). Intriguingly, in their study of pathogenesisrelated expression of putative cell-death regulator genes, Hückelhoven and associates (2001) observed that an aspartic proteinase gene is upregulated after inoculation with the powdery mildew fungus Blumeria graminis f. sp. hordei. Since aspartic proteinases are thought to represent proteins that can disintegrate plant cells (Mutlu and Gal 1999), these authors speculate that this enzyme contributes to HR in barley. Hence, it is tempting to believe that the endoxylanase-inhibition function of TAXI emerged from a class of proteins that was already overexpressed during HR. After all, certain endoxylanases are known to cause hypersensitive-like cell death. Besides, several studies supplying evidence for a role of aspartic proteinases in plant defense response have been published (Guevara et al. 2005; Xia et al. 2004).

Thirdly, TAXI, as well as XIP, proteins have been demonstrated to be wound and pathogen inducible. Igawa and associates (2004) reported that Taxi-I, Taxi-III, and Taxi-IV are strongly expressed in wounded wheat leaves. When challenged by fungal phytopathogens Fusarium graminearum and Erysiphe graminis, the concentrations of Taxi-III and Taxi-IV transcripts also increased significantly, whereas the increases in Taxi-I transcripts in response to these pathogens were rather limited (Igawa et al. 2004). Therefore, Taxi-I can be considered a basal preexisting defense gene, while Taxi-III and Taxi$I V$ are adaptively evolved pathogen-inducible Taxi-family members. In contrast to Taxi genes, Xip-I was not transcribed following inoculation with Fusarium graminearum of flowering spikelets (Igawa et al. 2005). However, Xip-I was strongly expressed in leaves by infection with Erysiphe graminis and also by wounding. Thus, unlike Taxi-I, Xip-I is pathogen inducible, and unlike Taxi-III and Taxi-IV, its expression depends on the type of phytopathogen, the infected tissue, or both. Besides their different induction pattern in different parts of the plant, Taxi and Xip mRNA levels were also found to vary during diverse developmental conditions (Igawa et al. 2005). A 
different spatiotemporal expression of endoxylanase inhibitors was observed earlier in studies based on immunodetection and measurements of endoxylanase inhibitor activity (Elliott et al. 2003; Goesaert et al. 2004). Additionally, Igawa and associates (2005) showed that expression of Xip-I but not Taxi genes is drastically elevated by treatment with methyl jasmonate, an essential signal involved in the particular defense or stress pathway (Schweizer et al. 1997). Furthermore, a proteomic study revealed the secretion of XIP-like proteins into the extracellular matrix of maize upon treatment with an elicitor preparation of Fusarium verticillioides (Chivasa et al. 2005). Taken together, the different expression profiles and interaction specificities displayed by TAXI and XIP might be indicative of distinct roles in plant defense depending on the type of plant, the part of the plant that is affected by the infection, the stage in plant development, and the type of pathogens or the nature of the isozyme secreted by a phytopathogen.

\section{Final remarks.}

In conclusion, structural and functional analysis of microbial endoxylanases and their inhibitors indicates that they are components of the offensive arsenal of phytopathogens and defense system of plants, respectively. The wide degree of functional redundancy and recognition specificity of endoxylanases as well as endoxylanase inhibitors maximizes the possibility of escaping inhibition from the pathogen viewpoint and counteracting cell-wall degradation from the plant viewpoint. In summarizing the recent advances in elucidation of inhibitor susceptibilities and perception of endoxylanases as elicitors, it is intriguing how subtle molecular determinants (often only a few amino-acid differences) that dictate recognition of these enzymes by plant inhibitors as well as plant receptors are. These highly specific interaction features are likely to be the result of coevolutionary adaptations characteristic of an arms race. Whether microbial endoxylanases significantly contribute to plant invasion or, rather, cause the activation of effective plant defense systems seems to depend on the outcome of this arms race.

\section{ACKNOWLEDGMENTS}

The authors wish to thank C. M. Courtin for critically reading the manuscript. The Instituut voor de aanmoediging van Innovatie door Wetenschap en Technologie in Vlaanderen (IWT, Brussels, Belgium) and "Bijzonder Onderzoeksfonds" (K.U.Leuven, Belgium) are gratefully acknowledged for financial support.

\section{LITERATURE CITED}

Apel, P. C., Pannacione, D. G., Holden, F. R., and Walton, J. D. 1993. Cloning and targeted disruption of XYL1, a $\beta-1,4$-xylanase gene from the maize pathogen Cochliobolus carbonum. Mol. Plant-Microbe Interact. 6:467-473.

Apel-Birkhold, P. C., and Walton, J. D. 1996. Cloning, disruption, and expression of two endo-beta 1, 4-xylanase genes, XYL2 and XYL3, from Cochliobolus carbonum. Appl. Environ. Microbiol. 62:4129-4135.

Atkinson, M. M. 1993. Molecular mechanisms of pathogen recognition by plants. Adv. Plant Pathol. 10:35-64.

Avni, A., Avidan, N., Eshed, Y., Zamir, D., Bailey, B. A., Stommel, J. R., and Anderson, J. D. 1994a. The response of Lycopersicon esculentum to a fungal xylanase is controlled by a single dominant gene. Plant Physiol. 105:S-158.

Avni, A., Bailey, B. A., Mattoo, A. K., and Anderson, J. D. 1994b. Induction of ethylene biosynthesis in Nicotiana tabacum by a Trichoderma viride xylanase is correlated to the accumulation of 1-aminocyclopropane-1-carboxylic acid (ACC) synthase and ACC oxidase transcripts. Plant Physiol. 106:1049-1055.

Bailey, B. A., Dean, J. F. D., and Anderson, J. D. 1990. An ethylene biosynthesis-inducing endoxylanase elicits electrolyte leakage and necrosis in Nicotiana tabacum cv. Xanthi leaves. Plant Physiol. 94:1849-1854.

Bailey, B. A., Korcak, R. F., and Anderson, J. D. 1992. Alteration in Nico- tiana tabacum L. cv. Xanthi cell membrane integrity following treatment with ethylene biosynthesis-inducing endoxylanase. Plant Physiol. 100:749-755.

Bailey, B. A., Korcak, R. F., and Anderson, J. D. 1993. Sensitivity to an ethylene biosynthesis-inducing endoxylanase in Nicotiana L. cv. Xanthi is controlled by a single dominant gene. Plant Physiol. 101:1081-1088.

Bargmann, B. O., Laxalt, A. M., Riet, B. T, Schouten, E., van Leeuwen, W., Dekker, H. L., de Koster, C. G., Haring, M. A., and Munnik, T. 2006. LePLD $\beta 1$ activation and relocalization in suspension-cultured tomato cells treated with xylanase. Plant J. 45:358-368.

Beaugrand, J., Gebruers, K., Ververken, C., Fierens, E., Croes, E. Goddeeris, B., Courtin, C. M., and Delcour, J. A. 2006. Antibodies against wheat xylanase inhibitors as tools for the selective identification of their homologues in other cereals. J. Cereal Sci. DOI:10.1016/j.jcs.2006.02.003. Published online.

Bedford, M. R., and Schulze, H. 1998. Exogenous enzymes for pigs and poultry. Nutr. Res. Rev. 11:91-114.

Beg, Q. K., Kapoor, M., Mahajan, L., and Hoondal, G. S. 2001. Microbial xylanases and their industrial applications: A review. Appl. Microbiol. Biotechnol. 56:326-338.

Beliën, T., Van Campenhout, S., Van Acker, M., and Volckaert, G. 2005. Cloning and characterization of two endoxylanases from the cereal phytopathogen Fusarium graminearum and their inhibition profile against endoxylanase inhibitors from wheat. Biochem. Biophys. Res. Commun. 327:407-414.

Biely, P., Vrsanska, M., Tenkanen, M., and Kluepfel, D. 1997. Endo-beta1,4-xylanase families: Differences in catalytic properties. J. Biotechnol. 57:151-166.

Bishop, J. G., Dean, A. M., and Mitchell-Olds, T. 2000. Rapid evolution in plant chitinases: Molecular targets of selection in plant-pathogen coevolution. Proc. Natl. Acad. Sci. U.S.A. 97:5322-5327.

Braun, E. J., and Rodrigues, C. A. 1993. Purification properties of an endoxylanase from a corn stalk rot of Erwinia chrysanthemi. Phytopathology 83:332-338.

Brito, N., Espino, J. J., and Gonzalez, C. 2006. The endo-beta-1,4xylanase xyn11A is required for virulence in Botrytis cinerea. Mol. Plant-Microbe Interact. 19:25-32.

Brutus, A., Villard, C., Durand, A., Tahir, T., Furniss, C., Puigserver, A., Juge, N., and Giardina, T. 2004. The inhibition specificity of recombinant Penicillium funiculosum xylanase B towards wheat proteinaceous inhibitors. Biochim. Biophys. Acta 1701:121-128.

Brutus, A., Reca, I. B., Herga, S., Mattei, B., Puigserver, A., Chaix, J. C., Juge, N., Bellincampi, D., and Giardina, T. 2005. A family 11 xylanase from the pathogen Botrytis cinerea is inhibited by plant endoxylanase inhibitors XIP-I and TAXI-I. Biochem. Biophys. Res. Commun. 337:160-166.

Bucheli, P., Doares, S. H., Albersheim, P., and Darvill, A. 1990. Hostpathogen interactions. XXXVI. Partial purification and characterization of heat-labile molecules secreted by the rice blast pathogen that solubilize plant cell wall fragments that kill plant cells. Physiol. Mol. Plant Pathol. 36:159-173.

Carlile, A. J., Bindschedler, L. V., Bailey, A. M., Bowyer, P., Clarkson, J. M., Cooper, R. M. 2000. Characterization of SNP1, a cell wall-degrading trypsin, produced during infection by Stagonospora nodorum. Mol. Plant-Microbe Interact. 13:538-550.

Carpita, N. C. 1996. Structure and biogenesis of the cell walls of grasses. Annu. Rev. Plant Physiol. Plant Mol. Biol. 4:445-476.

Chapman, K. D., Tripathy, S., Venables, B., and Desouza, A. D. 1998. $N$ acylethanolamines: Formation and molecular composition of a new class of plant lipids. Plant Physiol. 116:1163-1168.

Chivasa, S., Simon, W. J., Yu, X. L., Yalpani, N., and Slabas, A. R. 2005. Pathogen elicitor-induced changes in the maize extracellular matrix proteome. Proteomics 5:4894-4904.

Christophersen, C., Andersen, E., Jakobsen, T. S., and Bagsvaerd, P. W. 1997. Xylanases in wheat separation. Starch-Starke 49:5-12.

Christov, L. P., Szakacs, G., and Balakrishnan, H. 1999. Production, partial characterization and use of fungal cellulase-free xylanases in pulpbleaching. Process Biochem. 34:511-517.

Collins, T., Gerday, C., and Feller, G. 2005. Xylanases, xylanase families and extremophilic xylanases. FEMS (Fed. Eur. Microbiol. Soc.) Microbiol. Rev. 29:3-23.

Cooper, R. M., Longman, D., Campbell, A., Henry, M., and Lees, P. E. 1988. Enzymic adaptation of cereal pathogens to the monocotyledonous primary wall. Physiol. Mol. Plant Pathol. 32:33-47.

Courtin, C. M., Roelants, A., and Delcour, J. A. 1999. Fractionation-reconstitution experiments provide insight into the role of endoxylanases in bread-making. J. Agric. Food Chem. 47:1870-1877.

Dash, C., Ahmad, A., Nath, D., and Rao, M. 2001. Novel bifunctional inhibitor of xylanase and aspartic protease: Implications for inhibition of fungal growth. Antimicrob. Agents Chemother. 45:2008-2017. 
Davies, G. J., Wilson, K. S., and Henrissat, B. 1997. Nomenclature for sugar-binding subsites in glycosyl hydrolases. Biochem. J. 321:557559.

Dean, J. F. D., Gamble, H. R., and Anderson, J. D. 1989. The ethylene biosynthesis-inducing xylanase: Its induction in Trichoderma viride and certain plant pathogens. Phytopathology 79:1071-1078.

Debyser, W., Derdelinckx, G., and Delcour, J. A. 1997. Arabinoxylan solubilisation and inhibition of the barley malt xylanolytic system by wheat during brewing with wheat wholemeal adjunct: Evidence for a new class of enzyme inhibitors. J. Am. Soc. Brew. Chem. 55:153-156.

Degefu, Y., Paulin, L., and Lübeck, P. S. 2001. Cloning, sequencing and expression of a xylanase gene from the maize pathogen Helminthosporium turcicum. Eur. J. Plant Pathol. 107:457-465.

Degefu, Y., Lohtander, K., and Paulin, L. 2004. Expression patterns and phylogenetic analysis of two xylanase genes (htxyl1 and htxyl2) from Helminthosporium turcicum, the cause of northern leaf blight of maize. Biochimie 86:83-90.

De Lorenzo, G., D’Ovidio, R., and Cervone, F. 2001. The role of polygacturonase-inhibiting proteins (PGIPs) in defense against pathogenic fungi. Annu. Rev. Phytopathol. 39:313-335.

De Lorenzo, G., and Ferrari, S. 2002. Polygalacturonase-inhibiting proteins in defense against phytopathogenic fungi. Curr. Opin. Plant Biol. 5:295-299.

D’Ovidio, R., Mattei, B., Roberti, S., and Bellincampi, D. 2004. Polygalacturonases, polygalacturonase-inhibiting proteins and pectic oligomers in plant-pathogen interactions. Biochim. Biophys. Acta 1696:237-244.

Durand, A., Hughes, R., Roussel, A., Flatman, R., Henrissat, B., and Juge, N. 2005. Emergence of a subfamily of xylanase inhibitors within glycoside hydrolase family 18. FEBS (Fed. Eur. Biochem. Soc.) J. 272:17451755 .

Ebringerová, A., and Heinze, T. 2000. Xylan and xylan derivatives-Biopolymers with valuable properties. 1 . Naturally occurring xylan structures, isolation, procedures and properties. Macromol. Rapid Commun. 21:542-556

Elliott, G. O., Hughes, R. K., Juge, N., Kroon, P. A., and Williamson, G. 2002. Functional identification of the cDNA coding for a wheat endo1,4-beta-D-xylanase inhibitor. FEBS (Fed. Eur. Biochem. Soc.) Lett. 519:66-70.

Elliott, G. O., McLauchlan, W. R., Williamson, G., and Kroon, P. A. 2003. A wheat xylanase inhibitor protein (XIP-I) accumulates in the grain and has homologues in other cereals. J. Cereal Sci. 37:187-194.

Emami, K., and Hack, E. 2002. Conservation of XYN11A and XYN11B xylanase genes in Bipolaris sorghicola, Cochliobolus sativus, Cochliobolus heterotrophus, and Cochliobolus spicifer. Curr. Microbiol. 45:303306.

Enkerli, J., Felix, G., and Boller, T. 1999. The enzyme activity of fungal xylanase is not necessary for its elicitor activity. Plant Physiol. 121:391397.

Esquerré-Tugayé, M., Boudart, G., and Dumas, B. 2000. Cell wall degrading enzymes, inhibitory proteins, and oligosaccharides participate in the molecular dialogue between plants and pathogens. Plant Physiol. Biochem. 38:157-163.

Fierens, K., Brijs, K., Courtin, C. M., Gebruers, K., Goesaert, H., Raedschelders, G., Robben, J., Van Campenhout, S., Volckaert, G., and Delcour, J. A. 2003. Molecular identification of wheat endoxylanase inhibitor TAXI-I1, member of a new class of plant proteins. FEBS (Fed. Eur. Biochem. Soc.) Lett. 540:259-263.

Fierens K., Gils, A., Sansen, S., Brijs, K., Courtin, C. M., Declerck, P. J., De Ranter, C. J., Gebruers, K., Rabijns, A., Robben, J., Campenhout, S., Volckaert, G., and Delcour, J. A. 2005. His374 of wheat endoxylanase inhibitor TAXI-I stabilizes complex formation with glycoside hydrolase family 11 endoxylanases. FEBS (Fed. Eur. Biochem. Soc.) J. 272:58725882.

Flatman, R., McLauchlan, W. R., Juge, N., Furniss, C., Berrin, J. G., Hughes, R. K., Manzanares, P., Ladbury, J. E., O’Brien, R., and Williamson, G. 2002. Interactions defining the specificity between fungal xylanases and the xylanase-inhibiting protein XIP-I from wheat. Biochem. J. 365:773-781

Frederix, S. A., Courtin, C. M., and Delcour, J. A. 2004. Substrate selectivity and inhibitor sensitivity affect xylanase functionality in wheat flour gluten-starch separation. J. Cereal Sci. 40:41-49.

Furman-Matarasso, N., Cohen, E., Du, Q., Chejanovsky, N., Hanania, U., and Avni, A. 1999. A point mutation in the ethylene-inducing xylanase elicitor inhibits the $\beta$-1-4-endoxylanase activity but not the elicitation activity. Plant Physiol. 121:345-352.

Gebruers, K., Debyser, W., Goesaert, H., Proost, P., Van Damme, J., and Delcour, J. A. 2001. Triticum aestivum L. endoxylanase inhibitor (TAXI) consists of two inhibitors, TAXI I and TAXI II, with different specificities. Biochem. J. 353:239-244.

Gebruers K., Courtin, C. M., Goesaert, H., Van Campenhout, S., Delcour,
J. A. 2002. Endoxylanase inhibition activity in different European wheat cultivars and milling fractions. Cereal Chem. 795:613-616.

Gebruers, K., Brijs, K., Courtin, C. M., Goesaert, H., Raedschelders, G., Robben, J., Sørensen, J. F., Van Campenhout, S., and Delcour, J. A. 2004. Properties of TAXI-type endoxylanase inhibitors. Biochim. Biophys. Acta 1696:213-221.

Giesbert, S., Lepping, H. B., Tenberge, K. B., and Tudzynski, P. 1998. The xylanolytic system of Claviceps purpurea: Cytological evidence for secretion of xylanases in infected rye tissue and molecular characterization of two xylanase genes. Phytopathology 88:1020-1030.

Glazebrook, J. 2005. Contrasting mechanisms of defense against biotrophic and necrotrophic pathogens. Annu. Rev. Phytopathol. 43:205-227.

Goesaert, H., Elliott, G., Kroon, P. A., Gebruers, K., Courtin, C. M., Robben, J., Delcour, J. A., and Juge, N. 2004. Occurrence of proteinaceous endoxylanase inhibitors in cereals. Biochim. Biophys. Acta 1696:193-202.

Goesaert, H., Gebruers, K., Courtin, C. M., and Delcour, J. A. 2005. Purification and characterization of a XIP-type endoxylanase inhibitor from rice (Oryza sativa). J. Enzyme Inhib. Med. Chem. 20:95-101.

Gómez-Gómez, E., Roncero, M. I. G., Di Pietro, A., and Hera, C. 2001. Molecular characterisation of a novel endo-1,4- $\beta$-xylanase gene from the vascular wilt fungus Fusarium oxysporum. Curr. Genet. 40:268-275.

Gómez-Gómez, E., Roldán-Ruíz, M. C., Di Pietro, A., Roncero, M. I. G., and Hera, C. 2002. Role in pathogenesis of two endo- $\beta-1,4$ xylanase genes from vascular wilt fungus Fusarium oxysporum. Fungal Genet. Biol. 35:213-222.

Greenberg, J. T. 1997. Programmed cell death in plant-pathogen interactions. Annu Rev. Plant Physiol. Plant Mol. Biol. 48:525-545.

Guevara, M. G., Almeida, C., Mendieta, J. R., Faro, C. J., Verissimo, P., Pires, E. V., and Daleo, G. R. 2005. Molecular cloning of a potato leaf cDNA encoding an aspartic protease (StAsp) and its expression after $P$. infestans infection. Plant Physiol. Biochem. 43:882-889.

Hanania, U., and Avni, A. 1997. High affinity binding site for ethylene inducing xylanase elicitor on Nicotiana tabacum membranes. Plant J. 12:113-120.

Henrissat, B., and Davies, G. 1997. Structural and sequence-based classification of glycoside hydrolases. Curr. Opin. Struct. Biol. 7:637-644.

Hückelhoven, R., Dechert, C., Trujillo, M., and Kogel, K. H. 2001. Differential expression of putative cell death regulator genes in near-isogenic, resistant and susceptible barley lines during interaction with the powdery mildew fungus. Plant Mol. Biol. 47:739-748.

Hurlbert, J. C., and Preston, J. F. 2001. Functional characterization of a novel xylanase from corn strains of Erwinia chrysanthemi. J. Bacteriol.183:2093-2100.

Igawa, T., Ochiai-Fukuda, T., Takahashi-Ando, N., Ohsato, S., Shibata, T., Yamaguchi, I., and Kimura, M. 2004. New TAXI-type xylanase inhibitor genes are inducible by pathogens and wounding in hexaploid wheat. Plant Cell Physiol. 45:1347-1360.

Igawa, T., Tokai, T., Kudo, T., Yamaguchi, I., and Kimura, M. 2005. A wheat xylanase inhibitor gene, Xip-I, but not Taxi-I, is significantly induced by biotic and abiotic signals that trigger plant defense. Biosci. Biotechnol. Biochem. 69:1058-1063.

Ishii, S. 1988. Factors influencing protoplast viability of suspension cultured rice cells during isolation process. Plant Physiol. 88:26-29.

Juge, N., Payan, F., and Williamson, G. 2004. XIP-I, a xylanase inhibitor protein from wheat: A novel protein function. Biochim. Biophys. Acta 1696:203-211.

Keen, N. T., Boyd, C., and Henrissat, B. 1996. Cloning and characterization of a xylanase gene from corn strains of Erwinia chrysanthemi Mol. Plant-Microbe Interact. 9:651-657.

Kulkarni, N., Shendye, A., and Rao, M. 1999. Molecular and biotechnological aspects of xylanases. FEMS (Fed. Eur. Microbiol. Soc.) Microbiol. Rev. 23:411-456.

Laxalt, A. M., ter Riet, B., Verdonk, J. C., Parigi, L., Tameling, W. I., Vossen, J., Haring, M., Musgrave, A., and Munnik, T. 2001. Characterization of five tomato phospholipase D cDNAs: Rapid and specific expression of LePLDbeta1 on elicitation with xylanase. Plant J. 26:237247.

Lehtinen, U. 1993. Plant cell wall degrading enzymes of Septoria nodorum. Physiol. Mol. Plant Pathol. 43:121-134.

Lübeck, P. S., Paulin, L., Degefu, Y., Lübeck, M., Alekhina, I., Bulat, S. A., and Collinge, D. B. 1997. PCR cloning, DNA sequencing and phylogenetic analysis of a xylanase gene from the phytopathogenic fungus Ascochyta pisi Lib. Physiol. Mol. Plant Pathol. 51:377-389.

Matarasso N., Schuster S., and Avni, A. 2005. A novel plant cysteine protease has a dual function as a regulator of 1-aminocyclopropane-1-carboxylic acid synthase gene expression. Plant Cell 17:1205-1216.

Mayrose, M., Bonshtien, A., and Sessa, G. 2004. LeMPK3 is a mitogenactivated protein kinase with dual specificity induced during tomato defense and wounding responses. J. Biol. Chem. 279:14819-14827. 
McLauchlan, W. R., Garcia-Conesa, M. T., Williamson, G., Roza, M., Ravestein, P., Maat, J. 1999. A novel class of protein from wheat which inhibits xylanases. Biochem. J. 338:441-446.

Morel, J. B., and Dangl, J. L. 1997. The hypersensitive response and the induction of cell death in plants. Cell Death Differ. 4:671-683.

Mutlu, A., and Gal, S. 1999. Plant aspartic proteinases: Enzymes on the way to a function. Physiol. Plant. 105:569-576.

Naqvi, S. M., Harper, A., Carter, C., Ren, G., Guirgis, A., York, W. S., and Thornburg, R. W. 2005. Nectarin IV, a potent endoglucanase inhibitor secreted into the nectar of ornamental tobacco plants. Isolation, cloning, and characterization. Plant Physiol. 139:1389-1400.

Payan, F., Flatman, R., Porciero, S., Williamson, G., Juge, N., and Roussel, A. 2003. Structural analysis of xylanase inhibitor protein I (SIP-1), a proteinaceous xylanase inhibitor from wheat (Triticum aestivum, var. Soisson). Biochem J. 372:399-405.

Payan, F., Leone, P., Porciero, S., Furniss, C., Tahir, T., Williamson, G., Durand, A., Manzanares, P., Gilbert, H. J., Juge, N., and Roussel, A. 2004. The dual nature of the wheat xylanase protein inhibitor XIP-I: Structural basis for the inhibition of family 10 and family 11 xylanases. J. Biol. Chem. 279:36029-36037.

Punja, Z. K., and Zhang, Y. Y. 1993. Plant chitinases and their roles in resistance to fungal diseases. J. Nematol. 25:526-540.

Qin, Q., Bergmann, C. W., Rose, J. K., Saladie, M., Kolli, V. S., Albersheim, P., Darvill, A. G., and York, W. S. 2003. Characterization of a tomato protein that inhibits a xyloglucan-specific endoglucanase. Plant J. 34:327-338.

Raedschelders, G., Debefve, C., Goesaert, H., Delcour, J. A., Volckaert, G., and Van Campenhout, S. 2004. Molecular identification and chromosomal localization of genes encoding Triticum aestivum xylanase inhibitor I-like proteins in cereals. Theor. Appl. Genet. 109:112-121.

Raedschelders, G., Fierens, K., Sansen, S., Rombouts, S., Gebruers, K. Robben, J., Rabijns, A., Courtin, C. M., Delcour, J. A., Van Campenhout, S., and Volckaert, G. 2005. Molecular identification of wheat endoxylanase inhibitor TAXI-II and the determinants of its inhibition specificity. Biochem. Biophys. Res. Commun. 335:512-522.

Rajeshwari, R., Jha, G., and Sonti, R. V. 2005. Role of an in planta-expressed xylanase of Xanthomonas oryzae pv. oryzae in promoting virulence on rice. Mol. Plant-Microbe Interact. 18:830-837.

Ray, S. K., Rajeshwari, R., and Sonti, R. V. 2000. Mutants of Xanthomonas oryzae pv. oryzae deficient in general secretory pathway are virulence deficient and unable to secrete xylanase. Mol. Plant-Microbe Interact. 13:394-401.

Ron, M., Kantety, R., Martin, G. B., Avidan, N., Eshed, Y., Zamir, D., and Avni A. 2000. High-resolution linkage analysis and physical characterization of the EIX-responding locus in tomato. Theor. Appl. Genet. 100:184-189.

Ron, M., and Avni, A. 2004. The receptor for the fungal elicitor ethyleneinducing xylanase is a member of a resistance-like gene family in tomato. Plant Cell 16:1604-1615.

Rotblat, B., Enshell-Seijffers, D., Gershoni, J. M., Schuster, S., and Avni, A. 2002. Identification of an essential component of the elicitation active site of the EIX protein elicitor. Plant J. 32:1049-1055.

Ruiz-Roldan, M. C., Di Pietro, A., Huertas-Gonzalez, M. D., and Roncero, M. I. 1999. Two xylanase genes of the vascular wilt pathogen Fusarium oxysporum are differentially expressed during infection of tomato plants. Mol. Gen. Genet. 261:530-536.

Rye, C. S., and Withers, S. G. 2000. Glycosidase mechanisms. Curr. Opin. Chem. Biol. 4:573-580.

Saha, B. C. 2000. $\alpha$-1-Arabinofuranosidases: Biochemistry, molecular biology and application in biotechnology. Biotechnol. Adv. 18:403-423.

Sahai, A. S., and Manocha, M. S. 1993. Chitinases of fungi and plants: Their involvement in morphogenesis and host-parasite interaction. FEMS (Fed. Eur. Microbiol. Soc.) Microbiol. Rev. 11:317-338.

Sancho, A. I., Faulds, C. B., Svensson, B., Bartolome, B., Williamson, G., and Juge, N. 2003. Cross-inhibitory activity of cereal protein inhibitors against alpha-amylases and xylanases. Biochim. Biophys. Acta 1650:136-144.

Sansen, S., De Ranter, C. J., Gebruers, K., Brijs, K., Courtin, C. M., Delcour, J. A., and Rabijns, A. 2004. Structural basis for inhibition of Aspergillus niger xylanase by triticum aestivum xylanase inhibitor-I. J. Biol. Chem. 279:36022-36028.

Satoh, S., Sturm, A., Fujii, T., and Chrispeels, M. J. 1992. cDNA cloning of an extracellular dermal glycoprotein of carrot and its expression in response to wounding. Planta 188:432-438.

Schulze Gronover, C., Schorn, C., and Tudzynski, B. 2004. Identification of Botrytis cinerea genes up-regulated during infection and controlled by the Galpha subunit BCG1 using suppression subtractive hybridization (SSH). Mol. Plant-Microbe Interact. 17:537-546.

Schwarz, P. B., Jones, B. L., and Steffenson, B. J. 2002. Enzymes associated with Fusarium infection of barley. J. Am. Soc. Brew. Chem.
60:130-134.

Schweizer, P., Buchala, A., Silverman, P., Seskar, M., Raskin, I., and Metraux, J. P. 1997. Jasmonate-inducible genes are activated in rice by pathogen attack without a concomitant increase in endogenous jasmonic acid levels. Plant Physiol. 114:79-88.

Shallom, D., and Shoham, Y. 2003. Microbial hemicellulases. Curr. Opin. Microbiol. 6:219-228.

Sharon, A., Fuchs, Y., and Anderson, J. D. 1993. The elicitation of ethylene biosynthesis by a Trichoderma xylanase is not related to the cell wall degradation activity of the enzyme. Plant Physiol. 102:1325-1329.

Sørensen, J. F., and Sibbesen, O. 2006. Mapping of residues involved in the interaction between the Bacillus subtilis xylanase A and proteinaceous wheat xylanase inhibitors. Protein Eng. Des. Sel. 19:205-210.

Subramaniyan, S., and Prema, P. 2002. Biotechnology of microbial xylanases: Enzymology, molecular biology, and application. Crit. Rev. Biotechnol. 22:33-64.

Sun, Q. H., Hu, J., Huang, G. X., Ge, C.., Fang, R. X., and He, C. Z. 2005. Type-II secretion pathway structural gene xpsE, xylanase- and cellulase secretion and virulence in Xanthomonas oryzae pv. oryzae. Plant Pathol. 54:15-21.

Sunna, A., and Antranikian, G. 1997. Xylanolytic enzymes from fungi and bacteria. Crit. Rev. Biotechnol. 17:39-67.

Suzuki, K., Yano, A.., and Shinshi, H. 1999. Slow and prolonged activation of the p47 protein kinase during hypersensitive cell death in a culture of tobacco cells. Plant Physiol. 119:1465-1472.

Suzuki, K., Nishiuchi, T., Nakayama, Y., Ito, M., and Shinshi, H. 2006. Elicitor-induced down-regulation of cell cycle-related genes in tobacco cells. Plant Cell Environ. 29:183-191.

Tahir, T. A., Berrin, J. G., Flatman, R., Roussel, A., Roepstorff, P., Williamson, G., and Juge N. 2002. Specific characterization of substrate and inhibitor binding sites of a glycosyl hydrolase family $11 \mathrm{xy}-$ lanase from Aspergillus niger. J. Biol. Chem. 277:44035-44043.

Tahir, T. A., Durand, A., Gebruers, K., Roussel, A., Williamson, G., and Juge, N. 2004. Functional importance of Asp37 from a family 11 xylanase in the binding to two proteinaceous xylanase inhibitors from wheat. FEMS (Fed. Eur. Microbiol. Soc.) Microbiol. Lett. 239:9-15.

Tonukari, N. J., Scott-Craig, J. S., and Walton, J. D. 2000. The Cochliobolus carbonum SNF1 gene is required for cell-wall degrading enzyme expression and virulence on maize. Plant Cell 12:237-247.

Tonukari, N. J., Scott-Craig, J. S., and Walton, J. D. 2002. Influence of carbon source on the expression of Cochliobolus carbonum xylandegrading enzyme genes. Afr. J. Biotechnol. 1:64-66.

Törrönen, A., Harkki, A., and Rouvinen, J. 1994. Three-dimensional structure of endo-1,4-beta-xylanase II from Trichoderma reesei: Two conformational states in the active site. EMBO (Eur. Mol. Biol. Organ.) J. 13:2493-2501

Törrönen, A., and Rouvinen, J. 1997. Structural and functional properties of low molecular weight endo-1,4-beta-xylanases. J. Biotechnol. 57:137-149.

Tripathy, S., Venables, B. J., and Chapman, K. D. 1999. $N$-acylethanolamines in signal transduction of elicitor perception. Attenuation of alkalinization response and activation of defense gene expression. Plant Physiol. 121:1299-1308.

Tripathy, S., Kleppinger-Sparace, K., Dixon, R. A., and Chapman, K. D. 2003. $\mathrm{N}$-acylethanolamine signaling in tobacco is mediated by a membrane-associated, high-affinity binding protein. Plant Physiol. 131:1781-1791.

Trogh, I., Sørensen, J. F., Courtin, C. M., and Delcour, J. A. 2004. Impact of inhibition sensitivity on endoxylanase functionality in wheat flour breadmaking. J. Agric. Food Chem. 52:4296-4302.

van der Luit, A. H., Piatti, T., van Doorn, A., Musgrave, A., Felix, G., Boller, T., and Munnik, T. 2000. Elicitation of suspension-cultured tomato cells triggers the formation of phosphatidic acid and diacylglycerol pyrophosphate. Plant Physiol. 123:1507-1516.

von Tiedemann, A. 1997. Evidence for a primary role of active oxygen species in induction of host cell death during infection of bean leaves with Botrytis cinerea. Physiol. Mol. Plant Pathol. 50:151-166.

Walton, J. D. 1994. Deconstructing the cell wall. Plant Physiol. 104:11131118

Wanjiru, W. M., Zhensheng, K., and Buchenauer, H. 2002. Importance of cell wall degrading enzymes produced by Fusarium graminearum during infection of wheat heads. Eur. J. Plant Pathol. 108:803-810.

Wu, S. C., Kauffmann, S., Darvill, A. G., and Albersheim, P. 1995. Purification, cloning and characterization of two xylanases from Magnaporthe grisea, the rice blast fungus. Mol. Plant-Microbe Interact. 8:506-514.

Wu, S. C., Halley, J. E., Luttig, C., Fernekes, L. M., Gutierrez-Sanchez, G., Darvill, A. G., and Albersheim, P. 2006. Identification of an endobeta-1,4-D-xylanase from Magnaporthe grisea by gene knockout analysis, purification, and heterologous expression. Appl. Environ. Microbiol. 72:986-993. 
Xia, Y., Suzuki, H., Borevitz, J., Blount, J., Guo, Z., Patel, K., Dixon, R. A., and Lamb, C. 2004. An extracellular aspartic protease functions in Arabidopsis disease resistance signaling, EMBO (Eur. Mol. Biol. Organ.) J. 23:980-988

Yamamoto, S., Suzuki, K., and Shinshi, H. 1999. Elicitor-responsive, ethylene-independent activation of GCC box-mediated transcription that is regulated by both protein phosphorylation and dephosphorylation in cultured tobacco cells. Plant J. 20:571-579.

Yamamoto, S., Nakano, T., Suzuki, K., and Shinshi, H. 2004. Elicitorinduced activation of transcription via $\mathrm{W}$ box-related cis-acting elements from a basic chitinase gene by WRKY transcription factors in tobacco. Biochim. Biophys. Acta 1679:279-287.

Yang, K.-Y., Liu, Y., and Zhang, S. 2001. Activation of a mitogen-activated protein kinase pathway is involved in disease resistance in tobacco. Proc. Natl. Acad. Sci. U.S.A. 98:741-746.

Yano, A., Suzuki, K., and Shinshi, H. 1999. A signaling pathway, independent of the oxidative burst, that leads to hypersensitive cell death in cultured tobacco cells includes a serine protease. Plant J. 18:105109.

Yap, Y. K., Kodama, Y., Waller, F., Chung, K. M., Ueda, H., Nakamura, K. Oldsen, M., Yoda, H., Yamaguchi, Y., and Sano, H. 2005. Activation of a novel transcription factor through phosphorylation by WIPK, a wound-induced mitogen-activated protein kinase in tobacco plants. Plant Physiol. 139:127-137.

Yu, X. M., and Guo, S. X. 2000. Progress on plant chitinase induced by fungi. Prog. Biochem. Biophys. 27:40-44.

Zhang, S., and Liu, Y. 2001. Activation of salicylic acid-induced protein kinase, a mitogen-activated protein kinase, induces multiple defense responses in tobacco. Plant Cell 13:1877-1889.

AUTHOR-RECOMMENDED INTERNET RESOURCE

Pfam database: www.sanger.ac.uk/Software/Pfam 